\section{Aeronautical Development in Australia}

Is pursuance of its policy of encouraging aeronautical development in the Commonwealth, the Australian Government announced some time ago that it would assist in the initiation and maintenance of a chair of aeronautics at one of the universities. The choice lay between Sydney and Melbourne, with much to be said in favour of each. On the balance, it has been decided that Sydney is the more appropriate place, and steps will be taken at once to establish a school. The Government will provide $£ 32,000$ for capital expenditure and $£ 3,000$ per annum for maintenance. The Commonwealth Government has also decided to lend its support to the further development of meteorological science, being led to this largely by the requirements of aircraft services, both military and civil. An associate professorship will be created in the University of Melboume, the Government contributing $£ 4,000$ for expenditure on equipment and $£ 1,500$ per annum for maintenance.

\section{Engineering Public Relations}

The recently formed Engineering Public Relations Committee, supported by fourteen of the leading professional engineers' institutions, has arranged for the delivery of a series of twelve lectures at the Mary Ward Settlement, Tavistock Place, W.C.1, on Tuesdays at 8 p.m., commencing on September 27. The first lecture is to be given by Lieut.-Colonel F. H. Budden, public relations officer of the Committee, on "The Engineer and the Community"; subsequent lectures will be given by other eminent engineers on their special subjects, emphasizing how engineers have contributed to the welfare of the community in the past, how they are planning for present development, and what will be the effect of such development on society in the future. Lectures 2-5 are specifically directed to the civil engineering of London, its roads, water-supply, buildings, and sanitation. The remaining lectures deal with the implications of this machine age; the mass-production of goods, generation of power, production of wealth, transport by road, rail, and air, and the effect of these and mechanical forms of entertainment on economic life. A syllabus of the lectures and tickets for the series (3s. 6d.) can be obtained from the Mary Ward Settlement.

\section{Announcements}

Prof. C. O. E. Bergstrand, professor of astronomy in the University of Uppsala, has been elected correspondant for the Section of Astronomy of the Paris Academy of Sciences, in succession to Prof. L. Picart, professor of astronomy in the University of Bordeaux, who has been made a non-resident member of the Academy.

DR. H. J. S. SAND, head of the Department of Inorganic and Physical Chemistry at the Sir John Cass Technical Institute, London, E.C.3, is retiring at Christmas. Dr. E. de Barry Barnett, at present head of the Department of Organic and Applied Chemistry, has been appointed head of the combined chemistry departments as from January 1, 1939.
ON the occasion of the centenary celebration of Dalhousie University, Halifax, Nova Scotia, the honorary degree of LL.D. will be bestowed on Lord Macmillan, Sir Walter Langdon-Brown and Prof. Ernest Barker.

The Bavarian Academy of Sciences has presented the silver medal Bene Merenti to the pharmacologist Dr. Ernst Frickhinger of Nördlingen.

A Dutch Congress of public health will be held at Maestricht on September 15-17. Further information can be obtained from Prof. C. T. Van Oyen, Billstraat 166, Utrecht.

THE twelfth Congress of Anæsthesia will be held in New York on October 16-20. Further information can be obtained from Dr. F. H. McMechan, 318 Hotel Westlake, Rocking River, Ohio.

The 1938-39 session of the Royal Sanitary Institute courses of lectures will begin on Monday, September 19. The courses will be for sanitary inspectors, inspectors of meat and other foods, smoke inspectors, and will also deal with hygiene and sanitation in general and sanitary science applied to buildings and public works. Further information can be obtained from the Secretary, 90 Buckingham Palace Road, S.W.1.

DR. I. SNAPPER, professor of medicine in the University of Amsterdam and director of the clinic of internal medicine at the Wilhelmina Hospital, has been appointed professor of medicine at the Peiping Union Medical College.

ACCORDING to the central office of statistics of Poland, there has been a recent decline in the birthrate of that country. During the first six months of 1937 the births numbered 433,306 compared with 454,437 in the corresponding period of 1936 . During the same period of 1937 the number of deaths rose to 254,549 from 236,578 in the first half of 1936 , so that the increases of population fell from 217,859 to 178,757 or from 12.9 to 10.5 per 1,000 inhabitants.

A LEVERHULme research grant has been awarded to Dr. G. E. Friend for an inquiry into gain and loss of weight of 5,000 boys in day and boarding schools as a possible manifestation of fatigue.

The Commission for the Special Areas has made a grant of $£ 50,000$ for the centenary appeal fund of the Cardiff Royal Infirmary for the purpose of reconstruction, on the condition that the infirmary shall join a regional scheme for the co-ordination of hospital facilities and services in the special area.

Erratum. In Nature of August 13, p. 289, letter entitled "Radio Fadeouts, Auroras and Magnetic Storms", first paragraph, last line, for "January 20-22 and January 24-26, 1937" read "January 20-22 and January 24-26, 1938". 